\title{
Digitisation and Industry 4.0 in the Portuguese T\&C sector
}

\author{
DOI: $10.35530 / I T .070 .04 .1612$
}

HA LUU

ANTÓNIO DINIS MARQUES

FERNANDO FERREIRA

\section{REZUMAT - ABSTRACT}

\section{Digitalizarea și Industria 4.0 în sectorul textile şi îmbrăcăminte din Portugalia}

Industria 4.0 este un subiect cheie în discuția despre viitorul industriei textile și de îmbrăcăminte (T\&C) din Europa. Această a patra Revoluție industrială este o viziune, o schimbare importantă a paradigmei actuale, capabilă să facă convergența între lumea reală și cea digitală în viitoarea "fabrică inteligentă". Integrarea Sistemelor fizico-cibernetice (CPS), Internetul Lucrurilor (IoT), Analiza Big Data și Cloud Computing, Inteligența Artificială, Robotica, Modelarea Virtuală sau Digitalizarea proceselor industriale reprezintă câteva dintre pricipalele subiecte ale acestor noi provocări. Tehnologiile precum dispozitivele cu coduri de bare, RFID, senzori, Bluetooth, GPS sau simulatoare 3D încep să fie prezente în industria textilă și de îmbrăcăminte. Acest articol va prezenta modul în care o companie producătoare de îmbrăcăminte (GUIMA, SOMELOS SGPS) își definește strategia pentru a face față cerințelor clienților și părților interesate. Pentru a adapta teoriile și modelele cunoscute din cadrul 14.0 la realitatea companiei GUIMA, precum sistemul RFID în tesături și accesorii pentru a permite actualizarea în timp real a stocurilor, toată planificarea se face cu sistemul loS, iar încadrările și comenzile de producție sunt asistate de un sistem 3D și în diferite loturi sunt încorporate etichete RFID. Companiile TIC sunt parteneri deosebit de importanți în acest parteneriat, dar și instituțiile de învățământ superior, comunitatea științifică și centrele tehnologice.

Cuvinte-cheie: digitalizare, sisteme fizico-cibernetice, RFID, fabrică inteligentă

\section{Digitisation and Industry 4.0 in the Portuguese T\&C sector}

Industry 4.0 is a key topic in the discussion about the future of Textile and Clothing (T\&C) industry in Europe. This $4^{\text {th }}$ Industrial Revolution is a vision, an important change of the current paradigm, able to make the convergence between real and digital world in the future "smart factory". The integration of Cyber-Physical Systems (CPS), the Internet of the Things (IOT), the Big Data Analytics and Cloud Computing, Artificial Intelligence, Robotics, Virtual modelling or Digitisation of the industrial processes are some of the main topics in this new challenges. Technologies as barcode devices, RFID, sensors, Bluetooth, GPS or 3D simulators starts to be present in the textile and clothing industry. This article will present how a clothing company (GUIMA, SOMELOS SGPS) is defining its strategy to face the demanding from their clients and stakeholders. In order to adapt the theories and models known from 14.0 to GUIMA's reality, as RFID in the fabrics and accessories to allow real-time updates of the stocks, all the planning is done with the loS system, the cutting plans and production orders are assisted by a 3D system and the different batches are incorporated RFID tags. The ICT companies are critical partners in this partnership, but also the HEl, the scientific community and technological centres.

Keywords: Digitisation, Cyber-Physical Systems, RFID, smart factory

\section{INTRODUCTION}

Industry 4.0 is a key topic in the discussion about the future of Textile and Clothing (T\&C) industry in Europe. This $4^{\text {th }}$ Industrial Revolution is a vision, an important change of the current paradigm, able to make the convergence between real and digital world in the future "smart factory". The integration of CyberPhysical Systems (CPS), the Internet of the Things (loT) and Internet of Services (loS), the Big Data Analytics and Cloud Computing, Artificial Intelligence, Robotics, Virtual modelling or Digitisation of the industrial processes are some of the main topics in this new challenges [1]. The Digital Economy and Society Index 2017 shows that some Portuguese companies have integrated the Digital Technology in their processes: $44 \%$ of them are using Electronic Information
Sharing (EIS) and 8\% RFID (figure 1), but this data is different among industrial sectors [2].

Portugal has an important T\&C industry with more than 140000 workers, produces more than $€ 6000$ million, mainly to export [3]. This traditional and mature industry is facing these challenges and needs to prepare the correct approach to overcome future

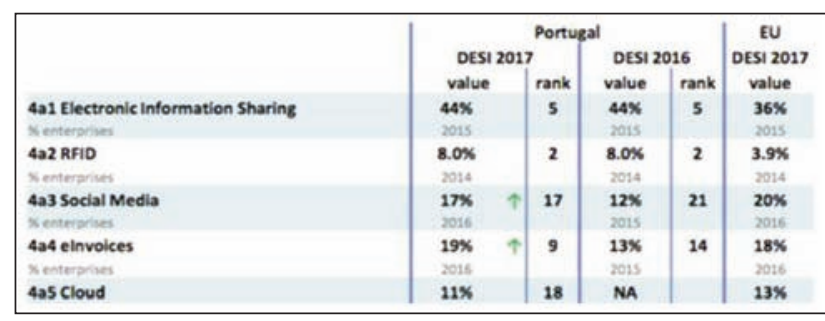

Fig. 1. Index of Integration of Digital Technology in Portugal and Europe 
difficulties and risks. Technologies as barcode devices, RFID, sensors, Bluetooth, GPS or 3D simulators starts to be present in the textile and clothing industry. The digitisation of the manufacturing is an ongoing approach in many factories, but requires skills and resources to be fully implemented [4].

This article will present how a clothing company is defining its strategy to face the demanding from their clients and stakeholders. But this new strategy to implement digitisation of the manufacturing in $T \& C$ is demanding also from their suppliers and other partners. The ICT companies are critical partners in this partnership, but also the HEI, the scientific community and technological centers and national authorities, as it happens in other countries [5]. CAD systems and automatic cutting it is been already used in GUIMA, and also IT in the stocks and warehouse, but the total integration of the data and digitisation of processes is not complete.

\section{EXPERIMENTAL APPROACH}

Apparel and footwear industries are considered "lowtech" industries, but already started the transition to a new technological level. This is the main aim to study the real application of some concepts and elements of Industry 4.0, including the integration of Digital Technology in the manufacturing processes of the Fashion Industry, mainly in Apparel and Footwear sectors.

As main result it is expected to obtain a characterization of a real case (Portuguese apparel company GUIMA, SOMELOS Group) concerning the integration of digital technology in the manufacturing processes and operations, quality, efficiency and productivity. There is a technological company inside the SOMELOS Group, called FLUXODATA - Aplicações Informáticas, Lda, with expertise and staff to develop, implement and control new ICT solutions to all the SOMELOS Group companies. Nowadays, the FLUXODATA is a ICT company having solutions to other T\&C firms, using an integrated module of textile solutions to manage and monitor daily industrial processes.

Qualitative research and case study methodology is of great convenience when the researcher wants a deep understanding of the context and the research process, and is adjusted to exploratory and explanatory studies of certain events or situations. This is also the strategy that allows to the researchers obtain holistic and relevant features of real events, regardless of the element of analysis is related with an individual, group or organization [6]. This is the opportunity to get a holistic view of a process, and is also a significant advantage for the case study strategy, when it is chosen [6]. Yin considers that a case study "is an empirical inquiry that investigates a contemporary phenomenon in depth and in the context of real life, explicitly when the boundaries between phenomenon and context are not clearly evident" (p.18) and are particularly useful when the researchers want to depth understand a specific organization or situation as it is with GUIMA [6]. Simons states that case study "is a deep exploration of multiple perspectives of the complexity and uniqueness of a particular project, a policy, an institution, a program or a system in a real-life context" (p. 21) [7]. The linkage between GUIMA, FLUXODATA and SOMELOS TECIDOS as main fabric supplier (all SOMELOS Group companies) was the criteria to choose these cases.

\section{RESULTS AND DISCUSSION}

The Portuguese companies in traditional, mature and "low-tech" sectors as they are apparel and footwear are facing the new challenges of digitisation according their own resources and available skills. The starting point to the different companies varies inside the sectors and according the existence or not of strong clusters. In 2012, GUIMA started an analysis of the manufacturing processes and a reorganization along the shop-floor. With the support of ICT FLUXODATA, the work began with the necessary development of tools to digitalize all the processes from warehouse, reception of the fabrics and accessories, passing through the areas of production, quality control, follow-up and delivery to the customers. Four years later, the software "FLUXOCONF" was implemented in the GUIMA as an internal ICT solution to support warehouse's operation, shop-floor assembly control, production efficiency and manufacturing times. To accomplish these tasks, the software answer to five items: i) which batches are ready to go into production; ii) identify in real time what is in working process; iii) evaluation of productivity and efficiency levels of each worker; iv) follow-up of the batches and production orders in the process (according planning department); v) measure the global efficiency and production costs.

SOMELOS TECIDOS is the main GUIMA's fabrics supplier. SOMELOS Group is a vertical textile company, starting its industrial process with spinning operations, warping and sizing, weaving, dyeing and finishing, clothing production, and it ends with other textile services (software/ICT and industrial maintenance). FLUXOMES is the manufacturing execution system (MES) developed by FLUXODATA supporting the production management and control in the shopfloor, such as production planning and scheduling, material delivery and control, product quality management and control, production costs and operation's time control, and equipment management and maintenance inside the SOMELOS Group (figure 2). This software solution also is sold to other textile companies as software/ICT services.

The new industrial challenges in this new millennium are identified as "collaborative production management and control" using networking manufacturing technologies such as agile manufacturing, collaborative manufacturing, supply chain management, e-manufacturing and e-commerce [8], and searching for innovation themes as "Smart, high-performance materials", "Advanced digitised manufacturing, value 


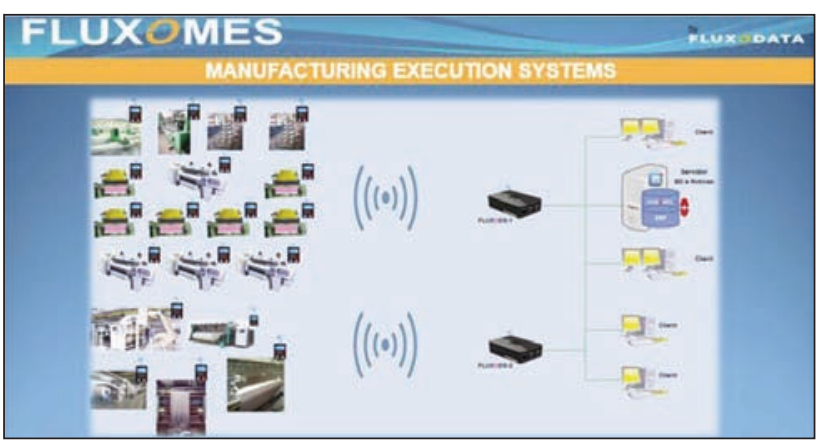

Fig. 2. FLUXOMES, manufacturing execution system from FLUXODATA

chains and business models", "Circular Economy and Resource Efficiency" and, finally, "High value added solutions for attractive growth markets" [9].

Considering the existing technology in shop-floor (warehouse, cutting, sewing machinery and transport between workstations), CAD/CAM to prepare the cutting plan, MES, ERP and MRP solutions, the analysis of future implementations is necessary and critical to the company.

In the warehouse, RFID can be used to identify the different fabrics, accessories and other materials stored in the racks, and barcodes as well. Smart sensors and wireless networks can be used to complete the ITC solutions available in this manufacturing sector. Furthermore, the implementation of these technologies and systems will help the commercial team and the administrators to adjust deadlines and optimize deliveries (GUIMA and SOMELOS TECIDOS have own products and collections, some of them to fast fashion industry, where the quick-response and short delivery times are critical). The production planning in GUIMA already benefits from FLUXOMES software and involves all the SOMELOS Group.

The cutting room has a CAD software to prepare the cutting plan according the customer order. The CAD workers place the different pattern pieces in the cutting plans and prepare the markers with the best solution (fabric usage, cutting time and productivity). With digitisation is possible to select the most suitable fabric rolls, reducing the fabric leftovers and finding the best width to achieve fabric savings. Spreading and cutting operations are monitored (using barcode scanners), providing reports that can be used for MRP (Material Requirement Planning) of further manufacturing processes [10]. Assembly operations will follow the technical instructions and get in workflow in batches with RFID tags (figure 3 ).

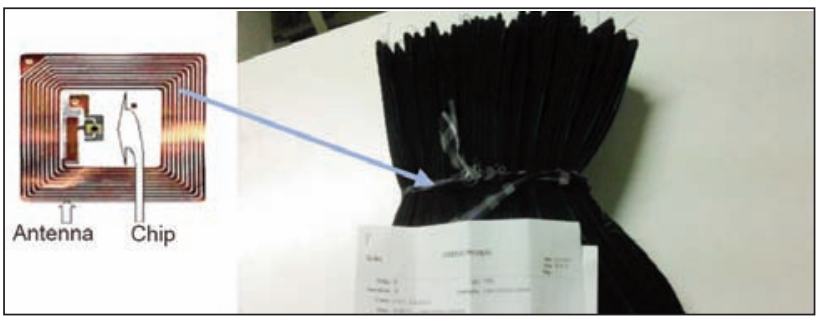

Fig. 3. Batch with RFID tag
All GUIMA sewing machines (and other machines) have a barcode reader where the operator inserts information's new batch. After that, the operator does the operations, the system records times and calculates efficiencies. Some activities of automation in clothing manufacturing system were considered before, such as workplace layout, work study analysis, time study and line balancing. To achieve next level in 14.0 process, it is necessary to implement RFID in all lean production (figure 4). The smart factory requires Cyber-Physical Systems allowing a continuous interaction and exchange of information, not only between operators, but also between operators and machines, and machine-to-machine [11]. Jiang defines two different CPS architectures in smart factories: CPS 5C Architecture and CPS 8C Architecture [12]. The CPS 5C was proposed by Lee et al [13] and has five levels: connection; conversion; cyber; cognition; configuration. GUIMA is doing first steps in this CPS model and needs to improve the skills of workers and machine's interface.

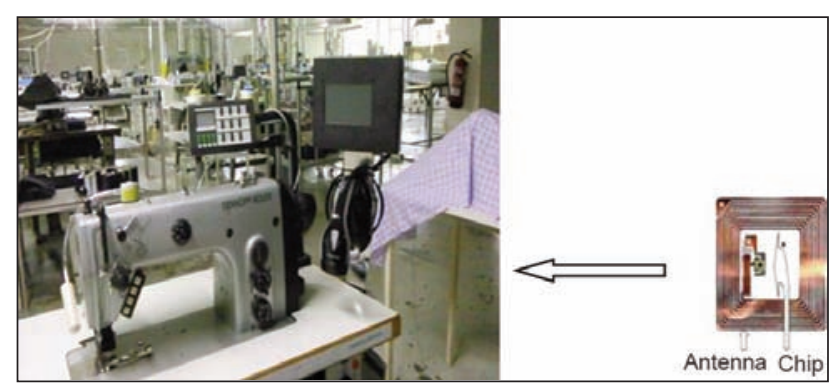

Fig. 4. Sewing machine with barcode scanner and RFID tag

In these circumstances, it is possible a reorganization of workflow and machines, making highly flexible the production and helping the line balancing and allowing small series and short delivery times. In the warehouse, the fabrics reception using RFID technology allows an easier stocks control of quantities of fabrics and accessories, real-time updated, without open the boxes. Also tablets, smart glasses or smart watches are some technologies will help the operators to take the best decisions during the manufacturing process.

\section{CONCLUSIONS}

Industry 4.0 is still in the early stages of implementation in fashion industry (textile, apparel and footwear) and scientific research. The introduction of the "FLUXOCONF" production monitoring program (software from FLUXODATA) was decisive for the evaluation of the technologies to be applied in GUIMA's production system. Being a standard application and an in-house ICT solution, the improvements to be introduced will contribute to the processes becoming flexible and easily reformulated. "FLUXOMES", being an in-house Manufacturing Execution System (MES) software, will make the connection between SOMELOS TECIDOS (fabrics supplier) and GUIMA as well. 
In order to adapt the theories and models known from 14.0 to GUIMA's reality, as RFID in the fabrics and accessories to allow real-time updates of the stocks, all the planning is done with the loS system, the cutting plans and production orders are assisted by a 3D system, the different batches incorporating RFID tags is allowing to get an interaction with the machines that will produce them in the workflow. CPS will connect the mechanical and electronic components to the ICT network, making the processes more flexible. Furthermore, CPS incorporated in the machines will evaluate the real-time production of equipment, allowing to schedule its maintenance and achieving a zero default situation. Finally, it will be easier improving and tuning the processes to the customization of the fashion products, as are nowadays the demands from new consumers.

\section{ACKNOWLEDGEMENTS}

"This work is financed by FEDER funds through the Competitivity Factors Operational Programme - COMPETE and by national funds through FCT - Foundation for Science and Technology within the scope of the project POCI-01-0145-FEDER-007136".

\section{BIBLIOGRAPHY}

[1] Ustundag, A., Cevikcan, E., Industry 4.0: Managing the Digital Transformation, Springer, Switzerland, 2018

[2] European Commission, Digital Economy and Society Index 2016 - Portugal, Available from https://ec.europa.eu/ digital-single-market/en/scoreboard/portugal, 2017, Accessed: 2018-05-02

[3] ATP, Estatísticas da ITV 2016, Edições da ATP, Porto, 2017

[4] Wang, S., Wan, J., Zhang, D., Li, D., Zhang, C., Towards smart factory for industry 4.0: a self-organized multi-agent system with big data based feedback and coordination, In: Computer Networks, 2016, 101, pp. 158-168

[5] Asalos, N., lordanescu, M., The contribution of clusters to increase the competitiveness of the textile and clothing industry. Cluster analysis using location quotient method, In: Industria Textila, 2015, 66, 6, pp. 370-379

[6] Yin, R. K., Case study research: Design and Methods, SAGE publications, Thousand Oaks, 2009

[7] Simons, H., Case study research in practice, SAGE publications, London, 2009

[8] Zhuang, C., Liu, J., Xiong, H., Digital twin-based smart production management and control framework for the complex product assembly shop-floor, In: The International Journal of Advanced Manufacturing Technology, Springer, 2018, 96, Issue 1-4, pp. 1149-1163

[9] ETP - European Technology Platform, Towards a 4th Industrial Revolution of Textiles and Clothing, Public Version Report, Textile ETP, Brussels, 2016

[10] Vilumsone-Nemes, I., Automation in spreading and cutting, In: Automation in Garment Manufacturing, Elsevier Woodhead Publishing, Duxford, 2018, pp. 139-163

[11] Roblek, V., Mesko, M., Krapez, A., A complex view of Industry 4.0, SAGE Open, 2016. pp. 1-11

[12] Jiang, J., An improved cyber-physical systems architecture for Industry 4.0 smart factories, In: Advances in Mechanical Engineering, 2018, 10, Issue 6, pp. 1-15

[13] Lee, J., Bagheri, B., Kao, H., A cyber-physical system architecture for Industry 4.0-based manufacturing systems, In: Manufacturing Letters, 2015, 3, pp. 18-23

\section{Authors:}

\section{HA LUU1 1 , FERNANDO FERREIRA², ANTÓNIO MARQUES ${ }^{2}$}

${ }^{1}$ Industrial University of Ho Chi Minh City, Faculty of Garment Technology and Fashion Design, No. 12 Nguyen Van Bao, Ward 4, Go Vap district, Ho Chi Minh City, Vietnam e-mail: haluusgn@gmail.com

2University of Minho, School of Engineering, Textile Department, Campus de Azurém, 4800-058, Guimarães, Portugal

e-mail: adinis@det.uminho.pt

Corresponding author:

ANTÓNIO DINIS MARQUES

e-mail: adinis@det.uminho.pt 